\title{
PENGARUH PROBLEM BASED LEARNING TERHADAP KETERAMPILAN BERPIKIR KRITIS DAN REGULASI DIRI SISWA KELAS V
}

\author{
THE EFFECT OF APPLYING PROBLEM-BASED LEARNING \\ TO CRITICAL THINKING SKILL AND SELF-REGULATION \\ OF $5^{\text {TH }}$ GRADERS
}

\author{
Pricilla Anindyta, Suwarjo \\ Universitas Katolik Indonesia Atmajaya Jakarta, Universitas Negeri Yogyakarta \\ anindyta_pricilla@yahoo.com, suwarjoraharjo@yahoo.com
}

\begin{abstract}
Abstrak
Penelitian ini bertujuan untuk mengetahui: (1) perbedaan keterampilan berpikir kritis dan regulasi diri siswa antara kelas yang diajar dengan menggunakan problem based leaning dan kelas yang diajar dengan menggunakan pembelajaran ekspositori dan (2) pengaruh penerapan problem based learning terhadap keterampilan berpikir kritis, dan regulasi diri siswa. Penelitian ini merupakan penelitian eksperimen semu. Populasi penelitian ini adalah seluruh siswa kelas V SD Santo Vincentius Jakarta. Pada kelas eksperimen, pembelajaran IPA dilaksanakan dengan model problem based learning, sedangkan pada kelas kontrol dengan pembelajaran yang biasa digunakan oleh guru yaitu pembelajaran ekspositori. Instrumen yang digunakan adalah (1) tes untuk mengukur keterampilan berpikir kritis siswa ditinjau dari aspek kognitif, (2) skala perilaku untuk mengukur keterampilan berpikir kritis ditinjau dari aspek perilaku dan regulasi diri siswa. Analisis data menggunakan (1) statistik deskriptif untuk mendeskripsikan data keterampilan berpikir kritis dan regulasi diri siswa, dan (2) statistik inferensial dengan menggunakan uji t sampel bebas dan uji MANOVA untuk menguji hipotesis penelitian dengan taraf signifikansi 5\% $(\alpha=0,05)$. Hasil penelitian menunjukkan bahwa: (1) terdapat perbedaan keterampilan berpikir kritis siswa yang signifikan antara kelas yang diajar dengan menggunakan problem based leaning dan kelas yang diajar dengan menggunakan pembelajaran ekspositori, dengan nilai sig. 0,040 ; (2) terdapat perbedaan regulasi diri siswa yang signifikan antara kelas yang diajar dengan menggunakan problem based learning dan kelas yang diajar dengan menggunakan pembelajaran ekspositori, dengan nilai sig. 0,005; (3) penerapan problem based learning berpengaruh secara positif dan signifikan terhadap keterampilan berpikir kritis dan regulasi diri siswa, dengan nilai sig 0,021.
\end{abstract}

Kata Kunci : Problem based learning, pembelajaran ekspositori, keterampilan berpikir kritis, regulasi diri.

\section{Abstract}

The objective of this research is to know: (1) the difference between the student's critical thinking skills and self regulation of the classes taught using problem based learning and expository learning, and (2) the effect of applying problem-based learning to student's critical thinking skill and self-regulation. This research is a quasi-experimental research study. The population of this research is all 5th graders of St. Vincentius, Jakarta. In the experimental class, science study was done by problem-based learning model, while in the control class by expository learning model. The instruments used are (1) a test to measure students' critical thinking skill reviewed from the cognitive aspect, (2) a scale of behavior to measure critical thinking skill reviewed from the behavioral aspect and students' self-regulation. Data analysis used (1) descriptive statistics to describe the data of students' critical thinking skill and selfregulation, and (2) inferential statistic by using independent sample t-test and MANOVA test to test the hypothesis of research with the significance level of $5 \%(\alpha=0,05)$. The results of this reseach have shown that: (1) there is a difference between the student's critical thinking skills of the classes taught using problem based learning and expository learning, with sig 0.040; (2) there is a difference between the student's self regulation of the classes taught using problem based learning and expository learning, with sig 0.005; (3) the application of problem-based learning positively and significantly influences students' critical thinking skill dan self regulation, with sig 0.021 .

Keywords: Problem-based learning, expository learning, critical thinking skill, self-regulation. 


\section{Pendahuluan}

Pembelajaran merupakan proses yang penting dalam sebuah penyelenggaraan pendidikan. Keberhasilan satuan pendidikan dalam rangka keikutsertaannya untuk mencapai tujuan pendidikan nasional, bergantung pada proses pembelajaran yang terjadi di kelas. Oleh karena itu, guru sebagai perancang dan pelaksana kegiatan pembelajaran memiliki peranan sentral guna mengembangkan potensi-potensi yang dimiliki siswa agar dapat mencapai kompetensi yang diharapkan. Menurut Rusmono (2012, p.6), pembelajaran merupakan suatu upaya untuk menciptakan suatu kondisi bagi terciptanya suatu kegiatan belajar yang memungkinkan siswa memperoleh pengalaman belajar yang memadai. Guru sebagai agen pembelajaran diharapkan dapat menciptakan pengalamanpengalaman yang bermakna bagi siswa melalui proses pembelajaran yang dilaksanakan. Harapannya adalah melalui pembelajaran yang telah dilakukan, dapat membawa pengaruh yang relatif permanen, baik pada aspek perilaku dan pengetahuan, maupun keterampilan-keterampilan berpikir siswa (Santrock, 2010, p.301).

Pada jenjang sekolah dasar, salah satu mata pelajaran pokok yang diajarkan adalah Ilmu Pengetahuan Alam (IPA). Pemahaman dan pengalaman guru berkaitan dengan proses pembelajaran membawa dampak pada aktivitas dan hasil pembelajaran yang dapat dicapai oleh siswa. IPA memiliki perbedaan dengan mata pelajaran lain yang diajarkan di sekolah. Berdasarkan cara mempelajarinya, sains memiliki empat dimensi yaitu (1) sains sebagai cara berpikir; (2) sains sebagai cara untuk menyelidiki; (3) sains sebagai pengetahuan; (4) sains dan interaksinya dengan teknologi dan masyarakat (Chiapetta \& Koballa, 2010, p.105). Pemahaman guru terhadap dimensi-dimensi sains ini berpengaruh pada aktivitas guru dalam merancang dan melaksanakan pembelajaran IPA di sekolah.

Berdasarkan survei awal yang dilakukan oleh peneliti pada pembelajaran IPA di kelas V SD Santo Vincentius, nampak guru menitikberatkan proses pembelajaran "sains sebagai pengetahuan". Penekanannya terletak pada apa yang harus diketahui oleh siswa berkaitan dengan materi IPA yang dipelajari. Prioritas dalam pembelajaran IPA yang dilaksanakan adalah bagaimana siswa dapat memperoleh pemahaman tentang sejumlah fakta, konsep, prinsip dan teori yang dipelajari. Hal ini terlihat dalam beberapa aktivitas yang dilakukan oleh siswa selama belajar IPA.

Beberapa aktivitas yang dilakukan oleh siswa antara lain membaca buku teks, mengerjakan lembar kerja siswa (LKS), membaca buku di perpustakaan atau mencari informasi dengan menggunakan fasilitas internet untuk memperoleh jawaban atas pertanyaan yang diberikan oleh guru. Dalam beberapa materi, siswa mengamati video yang ditunjukkan oleh guru, melakukan beberapa percobaan dan kuis.

Di dalam pembelajaran IPA, kegiatan kuis cukup sering diadakan dan siswa tampak antusias dalam mengikutinya. Dalam kegiatan ini, siswa memberikan pertanyaan kepada teman yang lain berdasarkan buku teks yang telah dibaca serta menjawab pertanyaan yang diberikan oleh temannya. Apabila siswa tidak dapat menjawab pertanyaan temannya, maka siswa tersebut diberi kesempatan untuk mencari jawabannya di dalam buku teks. Dalam mempelajari materi IPA, guru dan buku teks merupakan sumber belajar utama siswa. Belum terlihat adanya variasi dalam penggunaan sumber belajar lain, seperti internet, koran, ataupun lingkungan. Kebebasan siswa dalam memanfaatkan berbagai sumber belajar belum diakomodasi dalam proses pembelajarannya

Kegiatan penilaian yang dilakukan oleh guru sejalan dengan proses pembelajaran yang ada. Penilaian yang dilakukan oleh guru masih didominasi oleh penilaian yang berupa tes untuk mengukur keterampilan berpikir yang tergolong tingkat rendah. Sebagian besar pertanyaan diarahkan untuk menilai sejauh mana pemahaman siswa terhadap materi IPA yang telah dipelajari. Untuk penilaian yang berupa teknik non-tes belum digunakan secara optimal oleh guru.

Selain untuk memperoleh sejumlah pengetahuan, di dalam pembelajaran IPA juga perlu dipertimbangkan sebagai sebuah sarana untuk mengembangkan cara berpikir siswa. Bagaimana pengetahuan-pengetahuan tersebut tidak hanya diperoleh begitu saja secara pasif oleh siswa, namun melalui serangkaian kegiatan menganalisis dan mengevaluasi informasi yang diperoleh untuk memperoleh pengetahuan yang valid atau telah teruji kebenarannya. Melalui aktivitas tersebut, siswa dapat mengembangkan keterampilan berpikir kritisnya.

Menurut King, Goodson \& Rohani (1998, p.1), keterampilan berpikir kritis termasuk ke dalam keterampilan berpikir tingkat tinggi (higher order thinking skills). Menurut 
Bloom (Moore \& Stanley, 2010, p.10), berpikir kritis berada termasuk ke dalam level berpikir tingkat tinggi yang mencakup: analisis, sintesis, dan evaluasi. Dalam perkembangannya, taksonomi Bloom mengalami perubahan dalam strukturnya. Perubahan struktur ini merupakan hasil revisi taksonomi Bloom yang dilakukan oleh Anderson \& Krathwohl (2010, p.42). Oleh karena itu, berdasarkan revisi perubahan kategori tersebut, kategori proses kognitif yang termasuk ke dalam berpikir kritis adalah menganalisis, mengevaluasi, dan mencipta. Facione (2011, p.10) menambahkan bahwa seorang pemikir yang kritis tidak hanya dicirikan oleh keterampilan kognitifnya saja. Namun, ciri lain yang dapat dilihat adalah bagaimana sikap (disposisi) yang ditunjukkan dalam menjalani kehidupannya sehari-hari. seorang pemikir kritis memiliki sikap ingin tahu (inquisitive), bijaksana (judicious), mencari kebenaran (truthseeking), percaya diri dalam penalaran (confident in reasoning), terbuka (open-minded), analitis (analytical), dan sistematis (systematic).

Berdasarkan kajian yang dilakukan oleh sebuah lembaga yang bernama Partnership for 21 st century skills $(2009, \mathrm{p} .1)$, keterampilan berpikir kritis merupakan salah satu keterampilan esensi yang harus dimiliki oleh siswa. Keterampilan ini sangat bermanfaat bagi siswa dalam menghadapi kondisi yang ada di masyarakat saat ini. Di dalam era globalisasi yang sejalan dengan perkembangan IPTEK yang pesat, beragam informasi dapat diperoleh dan diakses melalui media yang tidak terbatas jumlahnya. Informasi yang beragam tersebut dapat mengandung hal yang positif dan negatif, yang secara langsung maupun tidak langsung dapat mempengaruhi siswa. Oleh karena itu, dengan keterampilan berpikir kritis yang dimiliki, siswa diharapkan tidak menerima informasi dengan begitu saja tanpa memilah mana informasi yang bermanfaat atau tidak bagi dirinya.

Di sekolah, pengembangan keterampilan berpikir kritis siswa belum sepenuhnya difasilitasi melalui kegiatan pembelajaran yang ada. Brooks \& Brooks (Santrock, 2010, p.359), mengungkapkan bahwa hanya sedikit sekali sekolah yang benar-benar mengajar murid untuk berpikir kritis. Menurut mereka, sekolah terlalu menghabiskan waktu untuk mengajar anak memberi satu jawaban benar yang imitatif. Banyak murid yang sukses menyelesaikan tugasnya, mengerjakan ujian dengan baik, dan mendapat nilai baik, tetapi mereka tidak belajar secara kritis dan mendalam.
Selain pemahaman terhadap karakteristik mata pelajaran IPA, guru juga perlu mengetahui lebih jelas tentang tujuan pembelajaran IPA di sekolah dasar. Menurut Howe \& Jones (1993, p.17), salah satu tujuan yang penting dalam pembelajaran IPA di sekolah dasar ialah menghubungkan apa yang siswa pelajari di sekolah dengan kehidupan sehari-hari. Namun, selama ini dalam mengajarkan IPA, guru kurang memperhatikan masalah-masalah yang menyangkut kehidupan nyata. Dengan menghubungkan pelajaran IPA dengan kehidupan nyata, siswa dapat merasakan adanya kegunaan dalam mempelajarinya. Apabila siswa terlibat dalam aktivitas yang berhubungan dengan masalah-masalah tersebut, siswa dapat mengetahui mengapa atau untuk apa mereka mengerjakannya (Usman Samatowa, 2011, p.27).

Sebagai contoh, salah satu materi yang dipelajari di kelas $\mathrm{V}$ adalah peristiwa alam, seperti gempa bumi dan banjir. Kedua peristiwa alam ini, sering dijumpai oleh siswa di dalam kehidupan sehari-harinya. Pada tahun 2012, khususnya di wilayah DKI Jakarta, terjadi beberapa kali gempa bumi. Hal ini menyebabkan masyarakat, khususnya yang berada di gedunggedung yang tinggi merasa panik dan berhamburan keluar dari dalam gedung. Setelah kejadian ini, Badan Meteorologi, Klimatologi, dan Geofisika (BMKG) mengadakan simulasi dalam menghadapi gempa bumi. Lain halnya dengan peristiwa banjir yang ada di DKI Jakarta. Peristiwa ini merupakan peristiwa tahunan. Artinya, setiap tahunnya diprediksi DKI Jakarta akan mengalami banjir besar pada saat musim hujan. Walaupun peristiwa ini sering terjadi, namun hingga saat ini masalah banjir tersebut belum juga dapat teratasi.

Timbulnya kedua peristiwa alam ini membawa dampak negatif, baik bagi masyarakat maupun lingkungan. Kerugiannya dapat berupa banyaknya korban yang meninggal dan rusaknya lingkungan sekitar yang menjadi tempat hidup penduduk. Untuk memecahkan masalah tersebut diperlukan peranan aktif dari masyarakat dalam meminimalisir dampak negatif yang terjadi. Peranan aktif yang dimaksud berhubungan dengan perilaku masyarakat dalam meregulasi dirinya dalam upaya meningkatkan kewaspadaan dan juga berperan aktif dalam menjaga lingkungan.

Siswa sebagai bagian dari masyarakat juga diharapkan untuk ikut serta dalam memecahkan masalah tersebut. Dengan melihat kondisi yang ditemukan dalam kehidupan sehari- 
hari inilah, guru dapat mengarahkan pembelajaran. Dalam mempelajari gempa bumi dan banjir, siswa tidak hanya memperoleh pemahaman tentang bagaimana kedua peristiwa alam tersebut dapat terjadi dan dampaknya bagi manusia dan lingkungan, namun juga siswa dapat belajar untuk meregulasi dirinya. Dengan berkembangnya kemampuan regulasi diri siswa dalam upaya meningkatkan kewaspadaan terhadap gempa bumi dan upaya mencegah banjir, siswa dapat menunjukkan kontribusinya pada masyarakat dan lingkungan tempat tinggalnya.

Menurut Diaz, Neal \& AmayaWilliams (1990, p.130), regulasi diri dapat didefinisikan sebagai kapasitas siswa untuk merencanakan, memandu, dan mengawasi perilakunya sendiri dari dalam dan bersifat fleksibel sesuai dengan perubahan kondisi. Kemampuan regulasi ini tidak dapat berkembang begitu saja tanpa adanya dorongan dari orang maupun lingkungan sekitar. Di sekolah, guru dan teman sebaya merupakan salah satu pihak yang dapat membantu perkembangan regulasi diri ini melalui proses pembelajaran yang berlangsung di kelas.

Zimmerman (Schunk, 2012, p.560) menyatakan bahwa regulasi diri merupakan sebuah proses perputaran. Faktor-faktor yang berpengaruh pada proses ini biasanya berubah selama proses pembelajaran dan memerlukan pengawasan dari guru. Proses perputaran dalam regulasi diri dapat dilihat pada model fase regulasi diri yang tersaji pada gambar berikut ini.

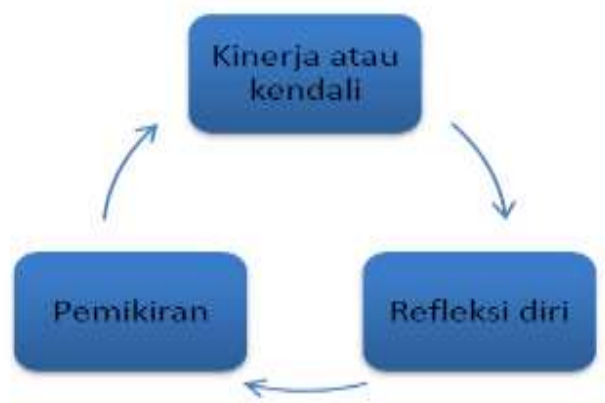

Gambar 1. Model Fase Regulasi Diri Menurut Zimmerman

Berdasarkan gambar 1, terlihat bahwa proses regulasi diri terdiri dari 3 tahap yang bersifat siklis. Pada fase pemikiran, siswa merancang tujuan yang hendak dicapai. Selain itu, siswa membuat perencanaan strategi yang hendak digunakan untuk dapat mencapai tujuan yang ditetapkan. Pada fase kinerja atau kendali, siswa menerapkan strategi yang sudah direnca- nakannya. Berikutnya, pada fase refleksi diri, siswa melakukan evaluasi diri.

Dalam melaksanakan pembelajaran, guru dapat menggunakan berbagai variasi model pembelajaran yang ada. Berdasarkan observasi yang telah dilakukan, peneliti melihat bahwa pembelajaran ekspositori merupakan pembelajaran yang paling sering diterapkan oleh guru. Penerapan pembelajaran ekspositori ini mempengaruhi keterlibatan siswa dalam proses pembelajarannya. Selama proses pembelajaran IPA berlangsung, terlihat sebagian besar aktivitas belajar yang dilakukan oleh siswa didasarkan pada arahan guru. Hal ini menyebabkan siswa terbiasa menjadi pebelajar yang pasif yang selalu bergantung pada gurunya dalam belajar.

Salah satu model pembelajaran yang disarankan dalam Kurikulum Tingkat Satuan Pelajaran (KTSP) untuk dapat diterapkan oleh guru dalam pembelajaran kelas adalah pembelajaran berbasis masalah (problem based learning). Model pembelajaran ini dipandang sebagai model pembelajaran yang inovatif yang menekankan pada kegiatan pembelajaran yang berpusat pada siswa dengan masalah sebagai acuan dalam proses pembelajarannya. Penerapan model pembelajaran ini memiliki manfaat ditinjau dari aspek teoritisnya. Menurut Christensen \& Martin (Killen, 2009, p.248), melalui kegiatan pemecahan masalah, siswa dapat mengembangkan keterampilan berpikir kritis. Selain itu, dapat membantu siswa untuk mengembangkan pemahaman yang mendalam mengenai konsep yang dipelajari dan pemahaman yang lebih baik mengenai kapan dan bagaimana siswa mengaplikasikan konsep tersebut.

Walaupun penerapan problem based learning dalam proses pembelajaran memiliki banyak manfaat. Namun, tidaklah mudah untuk mengimplementasikan model pembelajaran ini. Hal ini dikarenakan banyak tantangan yang harus dihadapi oleh guru dan siswa dalam penerapannya. Menurut Marx, et. al (Arends \& Kilcher, 2010, p.346), salah satu tantangan yang dihadapi oleh guru adalah model pembelajaran ini mengedepankan proses bukan konten pelajaran. Selama ini, dalam proses pembelajaran diarahkan agar siswa menguasai materimateri pelajaran sehingga produk pengetahuan merupakan prioritas utama dalam kegiatan pembelajaran. Sedangkan dalam problem based learning membangun keterikatan setiap siswa untuk dapat mengarahkan belajarnya sendiri 
agar mencapai pemahaman yang mendalam mengenai topik permasalahan yang dipelajari. Oleh karena itu, model pembelajaran ini tidak dapat digunakan apabila siswa tidak menguasai keterampilan dasar untuk bekerja secara mandiri (Killen, 2009, p.250).

Berdasarkan latar belakang permasalahan yang ada di SD Santo Vincentius berkaitan dengan pelaksanaan pembelajaran IPA yang telah diuraikan, masalah dapat diidentifikasi sebagai berikut: (1) Belum terungkapnya perbedaan keterampilan berpikir kritis dan regulasi diri siswa antara kelas yang diajar dengan menggunakan problem based learning dan kelas yang diajar dengan menggunakan pembelajaran ekspositori pada mata pelajaran IPA di SD Santo Vincentius; dan (2) Belum terungkapnya pengaruh penerapan problem based learning terhadap keterampilan berpikir kritis dan regulasi diri siswa pada pembelajaran IPA di SD Santo Vincentius.

Berdasarkan identifikasi masalah yang telah dipaparkan, maka masalah dapat dirumuskan sebagai berikut: (1) Apakah terdapat perbedaan keterampilan berpikir kritis siswa kelas V SD Santo Vincentius Jakarta antara kelas yang diajar dengan menggunakan problem based learning dan kelas yang diajar dengan menggunakan pembelajaran ekspositori pada mata pelajaran IPA?; (2) Apakah terdapat perbedaan regulasi diri siswa kelas V SD Santo Vincentius Jakarta antara kelas yang diajar dengan menggunakan problem based learning dan kelas yang diajar dengan menggunakan pembelajaran ekspositori pada mata pelajaran IPA?; dan (3) Apakah penerapan problem based learning berpengaruh terhadap keterampilan berpikir kritis dan regulasi diri siswa kelas $\mathrm{V}$ SD Santo Vincentius Jakarta pada mata pelajaran IPA?

Tujuan dari penelitian ini adalah untuk mengetahui: (1) Perbedaan keterampilan berpikir kritis siswa kelas V SD Santo Vincentius Jakarta antara kelas yang diajar dengan menggunakan problem based learning dan kelas yang diajar dengan menggunakan pembelajaran ekspositori pada mata pelajaran IPA; (2) Perbedaan regulasi diri siswa kelas V SD Santo Vincentius Jakarta antara kelas yang diajar dengan menggunakan problem based learning dan kelas yang diajar dengan menggunakan pembelajaran ekspositori pada mata pelajaran IPA; dan (3) Pengaruh penerapan problem based learning terhadap keterampilan berpikir kritis dan regulasi diri siswa kelas V SD Santo Vincentius Jakarta pada mata pelajaran IPA.

\section{Metode Penelitian}

Jenis Penelitian

Penelitian ini menggunakan pendekatan kuantitatif. Jenis penelitian ini adalah kuasi eksperimen. Desain eksperimen yang digunakan adalah pretest-postest control group design.

Waktu dan Tempat Penelitian

Kegiatan penelitian dilaksanakan di SD Santo Vincentius Jakarta Jl. Otto Iskandar Dinata No 76 Jakarta Timur. Waktu pelaksanaan kegiatan penelitian dimulai pada bulan Juli 2012 hingga bulan Agustus 2013.

Populasi dan Sampel Penelitian

Populasi penelitian ini adalah seluruh siswa kelas 5 SD Santo Vincentius yaitu siswa kelas VA dan VB. Penelitian ini merupakan penelitian populasi. Adapun jumlah siswa di masing-masing kelas adalah 16 orang laki-laki dan 19 orang perempuan. Jumlah total siswa di masing-masing kelas adalah 35 orang.

Prosedur

Desain eksperimen yang digunakan adalah pretest-postest control group design. Adapun desain eksperimen yang dipilih tersaji pada tabel berikut ini.

Tabel 1. Desain Eksperimen

\begin{tabular}{cccc}
\hline Kelompok & Pretes & Perlakuan & Postes \\
\hline $\mathrm{E}$ & $O_{1}$ & $X_{A}$ & $O_{2}$ \\
$\mathrm{~K}$ & $O_{3}$ & $X_{B}$ & $O_{4}$ \\
\hline
\end{tabular}

Keterangan:

E: Kelompok eksperimen

K: Kelompok kontrol

$\mathrm{O}_{1}$ : Pretes kelompok eksperimen

$\mathrm{O}_{2}$ : Postes kelompok eksperimen

$\mathrm{O}_{3}$ : Pretes kelompok kontrol

$\mathrm{O}_{4}$ : Postes kelompok kontrol

$X_{A}$ : Perlakuan kelompok eksperimen

$X_{B}$ : Perlakuan kelompok kontrol

Menurut Azwar (2012, p.118), dalam pretest-postest control group design, efek suatu perlakuan terhadap variabel dependen akan diuji dengan cara membandingkan keadaan variabel dependen pada kelompok eksperimen setelah dikenai perlakuan dengan kelompok kontrol yang tidak dikenai perlakuan. Berdasarkan desain tersebut, maka prosedur penelitian yang dilakukan adalah sebagai berikut: (1) 
Pelaksanaan tes awal; (2) Perlakuan dilakukan dalam 5 kali pertemuan sesuai dengan rancangan pembelajaran yang telah disusun; (3) Observasi dilakukan selama proses pembelajaran berlangsung; dan (4) Pelaksanaan tes akhir.

Data, Intrumen, dan Teknik Pengumpulan Data

Teknik pengumpulan data dalam penelitian ini adalah tes dan angket. Tes digunakan untuk mengukur keterampilan berpikir kritis. Tes yang dikembangkan berbentuk uraian dengan jumlah 12 soal. Pengembangan instrumen tes terdiri dari beberapa tahapan, yaitu: (1) mengkaji silabus mata pelajaran IPA kelas V SD; (2) menyusun kisi-kisi tes didasarkan pada teori yang dikembangkan oleh Bloom; (3) menulis butir soal; (4) menelaah butir soal; (5) melakukan uji coba; dan (6) menganalisis butir soal.

Angket digunakan untuk mengukur: (1) keterampilan berpikir kritis ditinjau dari aspek perilaku berpikir kritis; dan (2) regulasi diri siswa dalam kaitannya dengan topik yang dipelajari siswa yaitu gempa bumi dan banjir. Pengembangan instrumen skala perilaku berpikir kritis terdiri dari beberapa tahapan, yaitu: (1) mengkaji teori tentang keterampilan berpikir kritis dan regulasi diri; (2) membuat kisi-kisi angket perilaku berpikir kritis; (3) Penyusunan kisi-kisi skala perilaku untuk mengukur perila$\mathrm{ku}$ berpikir kritis didasarkan pada teori yang dikembangkan oleh Facione sedangkan kisi-kisi skala regulasi diri didasarkan pada teori yang dikembangkan oleh Zimmerman; (4) membuat instrumen; (5) melakukan uji coba instrumen; dan (6) merevisi instrumen berdasarkan hasil uji coba.

Dalam mengembangkan tes dan angket, dilakukan uji validitas instrumen. Penelitian ini menggunakan pengujian validitas isi dan konstruk dengan mengacu pada pendapat ahli (expert judgement). Penilaian terhadap validitas instrumen didasarkan pada pendapat ahli (expert judgement). Pada penelitian ini, validator instrumen adalah Ibu Dr. Insih Wilujeng, M.Pd.

Setelah proses validasi berdasarkan pendapat ahli dilakukan, instrumen diujicobakan pada siswa kelas V SD yang memiliki karakteristik yang hampir sama dengan siswa yang menjadi subjek penelitian ini. Sekolah yang dipilih sebagai tempat uji coba instrumen adalah SD RSBI Muhammadiyah Sagan dan SD Muhammadiyah Bausasran 1.
Data hasil uji coba instrumen skala perilaku berpikir kritis dan regulasi diri siswa yang telah diperoleh, digunakan untuk menguji validitas konstruk. Uji validitas skala menggunakan analisis faktor dengan bantuan komputer yakni menggunakan program SPSS 16.00 for windows. Untuk dapat dilakukan analisis faktor, terdapat syarat yang harus dipenuhi yaitu nilai Kaiser-Meyer-Olkin Measure of Sampling Adequacy (KMO MSA) harus > 0,50. Pada instrumen skala perilaku berpikir kritis diperoleh nilai KMO MSA sebesar 0,637 sedangkan nilai KMO MSA pada instrumen skala regulasi diri sebesar 0,583 . Oleh karena nilai KMO MSA yang diperoleh >0,50, maka prosedur analisis faktor dapat dilakukan.

Berdasarkan hasil analisis faktor yang telah dilakukan, pada instrumen skala perilaku berpikir kritis diperoleh 11 faktor yang memiliki nilai eigen > 1,0. Kesebelas faktor ini mampu menjelaskan perilaku berpikir kritis sebesar $75.507 \%$. Pada instrumen skala regulasi diri, diperoleh 8 faktor yang memiliki nilai eigen $>1,0$. Kedelapan faktor ini mampu menjelaskan regulasi diri sebesar $67,140 \%$.

Reliabilitas instrumen tes dan angket diuji dengan menggunakan alpha cronbach pada program SPSS 16.0 for Windows. Berdasarkan hasil uji coba instrumen, diperoleh nilai $r$ untuk instrumen tes keterampilan berpikir kritis, instrumen skala perilaku berpikir kritis, dan instrumen regulasi diri siswa secara berturut-turut adalah 0,$822 ; 0,917$ dan 0,787 .

\section{Teknik Analisis Data}

Teknik analisis data menggunakan dua jenis statistik, yaitu statististik deskriptif dan statistik inferensial. Statistik deskriptif digunakan untuk menyajikan data yang telah diperoleh melalui hasil pretest dan posttest variabel keterampilan berpikir kritis, perilaku berpikir kritis, dan regulasi siswa, baik pada kelompok eksperimen dan kelompok kontrol. Penyajian data berbentuk tabel yang mencakup rerata, standar deviasi, varian, skor minimum dan skor maksimum. Perhitungan statistik deskriptif ini menggunakan bantuan Ms. Excel dan Program SPSS 16.0 for windows. Berkaitan dengan jenis statistik inferensial, dalam penelitian ini teknik analisis data yang digunakan adalah teknik analisis uji $t$ sampel bebas dan uji MANOVA. Uji $t$ sampel bebas digunakan untuk melihat apakah terdapat perbedaan yang signifikan antara rerata kelompok eksperimen dan kelompok kontrol sedangkan uji MANOVA diguna- 
kan untuk melihat pengaruh penerapan problem based learning terhadap keterampilan berpikir kritis dan regulasi diri siswa.

Hipotesis statistik yang diuji pada penelitian ini menggunakan teknik analisis uji $t$ sebagai berikut.

Hipotesis 1:

Ho: $\mu A_{1}=\mu A_{2}$

Ha: $\mu A_{1} \neq \mu A_{2}$

Hipotesis 2:

Ho: $\mu B_{1}=\mu B_{2}$

Ha: $\mu B_{1} \neq \mu B_{2}$

Keterangan:

$\mu A_{1}$ : Rerata keterampilan berpikir kritis siswa yang mengikuti pembelajaran IPA melalui penerapan model problem based learning.

$\mu A_{2}$ : Rerata keterampilan berpikir kritis siswa yang mengikuti pembelajaran IPA melalui penerapan pembelajaran ekspositori.

$\mu B_{1}$ : Rerata regulasi diri siswa yang mengikuti pembelajaran IPA melalui penerapan problem based learning.

$\mu B_{2}$ : Rerata regulasi diri siswa yang mengikuti pembelajaran IPA melalui penerapan pembelajaran ekspositori.

Teknik analisis uji t sampel bebas dihitung dengan menggunakan bantuan program SPSS 16.00 for windows. Adapun kriteria pengambilan keputusan yang digunakan dalam penelitian ini adalah apabila nilai $t$ yang diperoleh lebih besar dari nilai $t$ tabel pada taraf signifikansi 0,05 maka Ho ditolak, berarti terdapat perbedaan yang signifikan antara rerata kelompok eksperimen dan kelompok kontrol.

Hipotesis statistik dengan menggunakan uji MANOVA adalah sebagai berikut:

Hipotesis 1:

Ho: $\tau A_{1}=\tau A_{2} \ldots=\tau_{g}=0$

Ha: paling sedikit satu tanda " $="$ tidak berlaku

Hipotesis 2:

Ho: $\tau B_{1}=\tau B_{2} \ldots=\tau_{g}=0$

Ha: paling sedikit satu tanda " $=$ " tidak berlaku

Keterangan:

$\tau A_{1}$ : Rerata keterampilan berpikir kritis siswa yang mengikuti pembelajaran IPA melalui penerapan model problem based learning.

$\tau A_{2}$ : Rerata keterampilan berpikir kritis siswa yang mengikuti pembelajaran IPA melalui penerapan pembelajaran ekspositori. $\tau B_{1}$ : Rerata regulasi diri siswa yang mengikuti pembelajaran IPA melalui penerapan problem based learning.

$\tau B_{2}$ : Rerata regulasi diri siswa yang mengikuti pembelajaran IPA melalui penerapan pembelajaran ekspositori.

Teknik analisis uji MANOVA dengan menggunakan tes signifikansi Hotelling's Trace dihitung dengan menggunakan bantuan program SPSS 16.00 for windows. Kriteria pengambilan keputusan yang digunakan dalam penelitian ini adalah apabila nilai $\mathrm{F}$ yang diperoleh lebih besar dari nilai $\mathrm{F}$ tabel dan pada taraf signifikansi <0,05 maka Ho ditolak, berarti terdapat pengaruh yang positif dan signifikan dari penerapan model problem based learning terhadap keterampilan berpikir kritis dan regulasi diri siswa.

Untuk dapat menggunakan teknik analisis uji $t$, maka sebelumnya dilakukan uji persyaratan hipotesis terlebih dahulu. uji persyaratan yang dilakukan adalah uji normalitas dan homogenitas. Uji normalitas digunakan untuk mengetahui apakah data dari masingmasing variabel berdistribusi normal atau tidak. Uji normalitas dilakukan terhadap data pretes baik pada kelompok eksperimen dan kelompok kontrol. Perhitungan uji normalitas dilakukan dengan menggunakan uji normalitas metode Kolmogorov Smirnov dengan fasilitas program SPSS 16.0 for windows. Hipotesis yang diajukan untuk mengukur normalitas ini adalah sebagai berikut.

Ho: Data berdistribusi normal

Ha: Data tidak berdistribusi normal

Adapun kriteria pengujian yang digunakan untuk mengukur normalitas populasi dalam penelitian ini adalah Ho diterima apabila nilai sig pada tabel $>\alpha$ yang ditetapkan yaitu 0,05 .

Uji homogenitas bertujuan untuk mengetahui apakah subjek penelitian berasal dari populasi yang homogen atau tidak homogen. Uji homogenitas ini dilakukan terhadap data pretes. Perhitungan uji homogenitas dilakukan dengan menggunakan homogenitas Levene. Hipotesis yang diajukan untuk mengukur homogenitas ini adalah sebagai berikut.

Ho: Varian variabel adalah sama (homogen)

Ha: Varian variabel adalah tidak sama (heterogen) 
Adapun kriteria pengujian yang digunakan untuk menentukan homogenitas varian dalam penelitian ini adalah Ho diterima apabila nilai sig $>\alpha$ yang ditetapkan 0,05 .

Selanjutnya, untuk dapat menggunakan teknik analisis uji MANOVA, maka dilakukan uji persyaratan terlebih dahulu. Adapun uji persyaratan yang dilakukan yaitu uji homogenitas varian dan uji homogenitas varian-covarian. Perhitungan uji homogenitas varians dilakukan dengan menggunakan homogenitas Levene. Hipotesis yang diajukan untuk mengukur homogenitas ini adalah sebagai berikut.

Ho: Varian variabel adalah sama (homogen)

Ha: Varian variabel adalah tidak sama (heterogen)

Adapun kriteria pengujian yang digunakan untuk menentukan homogenitas varian dalam penelitian ini adalah Ho diterima apabila nilai sig $>\alpha$ yang ditetapkan 0,05 .

Perhitungan uji homogenitas matriks varian-covarian dilakukan dengan menggunakan Box's Test. Hipotesis yang diajukan untuk mengukur homogenitas ini adalah sebagai berikut.

Ho: Matriks varian-covarians dari variabel dependen adalah sama (tidak berbeda)

Ha: Matriks varian-covarian dari variabel dependen adalah tidak sama (berbeda)

Adapun kriteria pengujian yang digunakan untuk menentukan homogenitas varian dalam penelitian ini adalah Ho diterima apabila nilai sig $>\alpha$ yang ditetapkan 0,05 .

\section{Hasil Penelitian dan Pembahasan}

Data tes keterampilan berpikir kritis terdiri dari data pretest dan posttest kelas kontrol dan kelas eksperimen. Data pretest menunjukkan kondisi awal berkaitan dengan keterampilan berpikir kritis siswa, baik di kelas kontrol maupun kelas eksperimen sebelum diberikan perlakuan berupa pembelajaran problem based learning. Data posttest menunjukkan kondisi berkaitan dengan keterampilan berpikir kritis siswa setelah diberikan perlakuan. Perolehan data keterampilan berpikir kritis tersaji pada tabel berikut ini.

Tabel 2. Rangkuman Data Keterampilan Berpikir Kritis

\begin{tabular}{lcccc}
\hline \multirow{2}{*}{ Deskripsi } & \multicolumn{2}{c}{ Kelas Kontrol $(\mathbf{n}=\mathbf{3 5})$} & \multicolumn{2}{c}{ Kelas Eksperimen $(\mathbf{n}=\mathbf{3 5})$} \\
\cline { 2 - 5 } & Pretest & Posttest & Pretest & Posttest \\
\hline Rata-rata & 122,54 & 132,94 & 126,43 & 140,91 \\
Standar Deviasi & 15,19 & 17,21 & 14,18 & 14,59 \\
Varians & 230,67 & 296,17 & 201,02 & 212,85 \\
Nilai Minimum & 90,00 & 94,00 & 100,00 & 105,00 \\
Nilai Maksimum & 159,00 & 178,00 & 166,00 & 173,00 \\
\hline
\end{tabular}

Berdasarkan tabel 2 yang disajikan, dapat diketahui bahwa sebelum diberikan perlakuan, rerata skor pretest pada kelas kontrol adalah 122,54, dengan skor minimum 90,00 dan skor maksimum 159,00. Rerata skor pretest pada kelas eksperimen adalah 126,43 dengan skor minimum 100 dan skor maksimum 166,00. Setelah diberi perlakuan, rerata skor posttest pada kelas kontrol adalah 132,94, dengan skor minimum 94 dan skor maksimum 178,00. Rerata skor posttest pada kelas eksperimen adalah 140,91, dengan skor minimum 105,00 dan skor maksimum 173,00.

Berdasarkan rerata skor pretest dan posttest yang diperoleh, dapat diketahui bahwa rerata skor keterampilan berpikir kritis siswa kelas kontrol mengalami peningkatan sebesar 10,4 , dari skor 122,54 menjadi 132,94 , sedang- kan rerata skor keterampilan berpikir kritis siswa kelas eksperimen mengalami peningkatan sebesar 14,48, dari skor 126,43 menjadi 140,91. Melalui perbandingan peningkatan skor antara kelas kontrol dan kelas eksperimen, dapat disimpulkan bahwa kelas eksperimen mengalami peningkatan skor yang lebih besar dibandingkan kelas kontrol.

Data regulasi diri siswa terdiri dari data pretest dan posttest kelas kontrol dan kelas eksperimen. Data pretest menunjukkan kondisi awal berkaitan dengan regulasi diri siswa, baik di kelas kontrol maupun kelas eksperimen sebelum diberikan perlakuan berupa pembelajaran problem based learning. Data posttest menunjukkan kondisi berkaitan dengan regulasi diri siswa setelah diberikan perlakuan. Perolehan data regulasi diri tersaji pada tabel berikut ini. 
Tabel 3. Rangkuman Data Regulasi Diri

\begin{tabular}{lcccc}
\hline \multirow{2}{*}{ Deskripsi } & \multicolumn{2}{c}{ Kelas Kontrol $(\mathbf{n}=35)$} & \multicolumn{2}{c}{ Kelas Eksperimen $(\mathbf{n}=\mathbf{3 5})$} \\
\cline { 2 - 5 } & Pretest & Posttest & Pretest & Posttest \\
\hline Rata-rata & 71,86 & 74,17 & 71,43 & 79,28 \\
Standar Deviasi & 8,35 & 7,68 & 7,57 & 7,16 \\
Varians & 69,81 & 58,97 & 57,31 & 51,27 \\
Nilai Minimum & 56,00 & 60,00 & 59,00 & 62,00 \\
Nilai Maksimum & 92,00 & 89,00 & 89,00 & 92,00 \\
\hline
\end{tabular}

Berdasarkan tabel 3 yang disajikan, dapat diketahui bahwa sebelum diberikan perlakuan, rerata skor pretest pada kelas kontrol adalah 71,86 , dengan skor minimum 56,00 dan skor maksimum 92,00. Rerata skor pretest pada kelas eksperimen adalah 71,43, dengan skor minimum 59,00 dan skor maksimum 89,00. Setelah diberi perlakuan, rerata skor posttest pada kelas kontrol adalah 74,17, dengan skor minimum 60,00 dan skor maksimum 89,00. Rerata skor posttest pada kelas eksperimen adalah 79,28, dengan skor minimum 62,00 dan skor maksimum 92,00.

Berdasarkan rerata skor pretest dan posttest yang diperoleh, dapat diketahui bahwa rerata skor regulasi diri siswa kelas kontrol mengalami peningkatan sebesar 2,31, dari skor 71,86 menjadi 74,17 , sedangkan rerata skor regulasi diri siswa kelas eksperimen mengalami peningkatan sebesar 7,85, dari skor 71,43 menjadi 79,28. Melalui perbandingan peningkatan skor antara kelas kontrol dan kelas eksperimen, dapat disimpulkan bahwa kelas eksperimen mengalami peningkatan skor yang lebih besar dibandingkan kelas kontrol.

Uji prasyarat $t$ test meliputi uji normalitas dan uji homogenitas. Uji normalitas bertujuan untuk mengetahui apakah subjek penelitian berasal dari populasi yang berdistribusi normal. Dalam melakukan uji normalitas ini, peneliti menggunakan metode Kolmogorov-Smirnov dengan bantuan program SPSS 16.0 for windows. Adapun hipotesis yang diajukan adalah sebagai berikut.

$H_{o}$ : Data berdistribusi normal.

$H_{a}$ : Data tidak berdistribusi normal.

Apabila nilai signifikansi yang diperoleh lebih besar dari alpha yang ditetapkan yaitu 5\%, maka $H_{o}$ diterima. Sebaliknya, apabila nilai signifikansi yang diperoleh lebih kecil dari alpha yang ditetapkan, maka $H_{0}$ ditolak. Hasil uji normalitas terhadap variabel keterampilan berpikir kritis dan regulasi diri pada kelas kontrol dan kelas eksperimen tersaji pada tabel berikut ini.

Tabel 4. Rangkuman Uji Normalitas Kelas Eksperimen dan Kelas Kontrol

\begin{tabular}{|c|c|c|c|c|c|c|}
\hline \multirow{4}{*}{ Variabel } & \multirow{2}{*}{\multicolumn{4}{|c|}{ Signifikansi Kolgomorov-Smirnov }} & \multirow{4}{*}{$\begin{array}{l}\text { Asymp Sig. (2- } \\
\text { tailed }\end{array}$} & \multirow{4}{*}{ Ket } \\
\hline & & & & & & \\
\hline & \multicolumn{2}{|c|}{$\begin{array}{l}\text { Kelas kontrol } \\
\quad(n=35)\end{array}$} & \multicolumn{2}{|c|}{ Kelas eksperimen $(n=35)$} & & \\
\hline & Pretest & Posttest & Pretest & Posttest & & \\
\hline Keterampilan berpikir kritis & 0,968 & 0,764 & 0,514 & 0,984 & Sig $>0,05$ & Normal \\
\hline Regulasi diri & 0,372 & 0,801 & 0,984 & 0,837 & $\mathrm{Sig}>0,05$ & Normal \\
\hline
\end{tabular}

Berdasarkan tabel 4 yang disajikan, dapat diketahui bahwa nilai signifikansi yang diperoleh kelas kontrol dan kelas eksperimen pada pretest dan posttest untuk variabel keterampilan berpikir kritis dan regulasi diri lebih besar dibandingkan alpha yang ditetapkan. Oleh karena itu, $H_{o}$ diterima dan dapat disimpulkan bahwa semua data berdistribusi normal.

Uji homogenitas bertujuan untuk mengetahui apakah subjek penelitian berasal dari populasi yang homogen atau tidak. Dalam melakukan uji normalitas ini, peneliti menggunakan Lavene dengan bantuan program SPSS 16.0 for windows. Adapun hipotesis yang diajukan adalah sebagai berikut.

$H_{o}$ : Varian variabel adalah sama (homogen)

$H_{\alpha}$ : Varian variabel adalah tidak sama (heterogen)

Apabila nilai signifikansi yang diperoleh lebih besar dari alpha yang ditetapkan yaitu $5 \%$, maka $H_{o}$ diterima. Sebaliknya, apabila nilai signifikansi yang diperoleh lebih kecil 
dari alpha yang ditetapkan, maka $H_{0}$ ditolak. Hasil uji homogenitas terhadap variabel keterampilan berpikir kritis dan regulasi diri pada

Tabel 5. Rangkuman Uji Homogenitas Kelas Kontrol dan Kelas Eksperimen

\begin{tabular}{cccccc}
\hline Variabel & Levene Statistic & Dfl & Df2 & Sig & Ket \\
\hline Keterampilan Berpikir kritis & 0,032 & 1 & 68 & 0,856 & Homogen \\
Regulasi diri & 0,042 & 1 & 68 & 0,838 & Homogen \\
\hline
\end{tabular}

Berdasarkan tabel 5 yang disajikan, dapat diketahui bahwa nilai signifikansi yang diperoleh kelas kontrol dan kelas eksperimen pada pretest untuk variabel keterampilan berpikir kritis dan regulasi diri lebih besar dibandingkan alpha yang ditetapkan. Oleh karena itu, Ho diterima dan dapat disimpulkan bahwa semua varian variabel adalah sama (homogen).

Uji prasyarat MANOVA meliputi uji homogenitas varian dan uji homogenitas variancovarian.Dalam melakukan uji homogenitas varians ini, peneliti menggunakan Lavene dengan bantuan program SPSS 16.0 for windows. Hipotesis yang diajukan adalah sebagai berikut.

$H_{o}$ : Varian variabel adalah sama (homogen)

$H_{\alpha}$ : Varian variabel adalah tidak sama (heterogen)

Apabila nilai signifikansi yang diperoleh lebih besar dari alpha yang ditetapkan yaitu $5 \%$, maka $H_{o}$ diterima. Sebaliknya, apabila nilai signifikansi yang diperoleh lebih kecil dari alpha yang ditetapkan, maka $H_{0}$ ditolak. Hasil uji homogenitas terhadap variabel keterampilan berpikir kritis dan regulasi diri pada kelompok kontrol dan kelompok eksperimen tersaji pada tabel 6 .

Tabel 6. Uji Homogenitas Varian

\begin{tabular}{lcccc}
\hline & F & df1 & df2 & Sig. \\
\hline Berpikir kritis & 0,139 & 1 & 68 & 0,710 \\
Regulasi diri & 0,123 & 1 & 68 & 0,727 \\
\hline
\end{tabular}

Berdasarkan uji homogenitas varian dengan menggunakan levene test yang tersaji pada tabel 6 , diketahui nilai signifikansi pada variabel keterampilan berpikir kritis dan regulasi diri siswa $>0.05$. Hal ini berarti kedua kelompok memiliki varian yang sama.

Dalam menguji homogenitas matriks varian/covarian, peneliti menggunakan Box's test. Adapun hipotesis yang diajukan adalah sebagai berikut.

Ho: Matriks varian-covarian dari variabel dependen adalah sama (tidak berbeda) kelompok kontrol dan kelompok eksperimen tersaji pada tabel berikut ini.

Ha: Matriks varian-covarian dari variabel dependen adalah tidak sama (berbeda)

Apabila nilai signifikansi yang diperoleh lebih besar dari alpha yang ditetapkan yaitu 5\%, maka $H_{o}$ diterima. Sebaliknya, apabila nilai signifikansi yang diperoleh lebih kecil dari alpha yang ditetapkan, maka $H_{o}$ ditolak. Hasil uji homogenitas terhadap variabel keterampilan berpikir kritis dan regulasi diri pada kelompok kontrol dan kelompok eksperimen tersaji pada tabel berikut ini.

Tabel 7. Uji Homogenitas Varian-covarian

\begin{tabular}{lcccc}
\hline & F & df1 & df2 & Sig. \\
\hline Berpikir kritis & 0,139 & 1 & 68 & 0,710 \\
Regulasi diri & 0,123 & 1 & 68 & 0,727 \\
\hline
\end{tabular}

Berdasarkan uji Box test yang tersaji pada tabel 7, diketahui nilai Box's M test sebesar 1,494 dan nilai $F$ test sebesar 0,482 dengan tingkat signifikansi 0,695 . Nilai signifikansi yang diperoleh $>0,05$ sehingga Ho diterima. Hal ini berarti matrik varian-covarian dari variabel dependen adalah sama (tidak berbeda).

Pada uji hipotesis pertama, hipotesis yang akan diuji adalah $H_{o}: \mu A_{1}=\mu A_{2}$ (Keterampilan berpikir kritis siswa tidak berbeda secara signifikan antara kelas yang diajarkan dengan menggunakan problem based learning dan kelas yang diajarkan dengan menggunakan pembelajaran ekspositori) melawan $H_{a}: \mu A_{1} \neq$ $\mu A_{2}$ (Keterampilan berpikir kritis siswa berbeda secara signifikan antara kelas yang diajarkan dengan menggunakan problem based learning dan kelas yang diajarkan dengan menggunakan pembelajaran ekspositori). Untuk menguji ada atau tidaknya perbedaan keterampilan berpikir kritis siswa kelas V SD Santo Vincentius pada mata pelajaran IPA, peneliti menggunakan independent sample t-test dengan bantuan program SPSS 16.0 for windows. Apabila nilai signifikansi yang diperoleh $>0,05$, maka $H_{\circ}$ diterima. Sebaliknya, apabila nilai signifikansi yang diperoleh $<0,05$, maka $H_{a}$ diterima. Hasil analisis data uji $t$ terhadap skor posttest 
keterampilan berpikir kritis tersaji pada tabel berikut ini.

Tabel 8. Uji $t$ Terhadap Skor Posttest Keterampilan Berpikir Kritis

\begin{tabular}{lllll}
\hline & & t & df & $\begin{array}{c}\text { Sig. (2- } \\
\text { tailed }\end{array}$ \\
\hline $\begin{array}{l}\text { Keterampilan } \\
\text { kritis }\end{array}$ & Berpikir & 2,090 & 68 & 0,040 \\
\hline
\end{tabular}

Berdasarkan tabel 8 yang disajikan, dapat diketahui bahwa nilai signifikansi yang diperoleh adalah sebesar 0,040. Nilai signifikansi yang diperoleh lebih kecil dibandingkan dengan nilai alpha yang telah ditetapkan yaitu 0,05, maka $H_{o}$ ditolak. Oleh karena itu, dapat disimpulkan bahwa terdapat perbedaan keterampilan berpikir kritis siswa yang signifikan antara kelas yang diajarkan dengan menggunakan problem based learning dan kelas yang diajarkan dengan menggunakan pembelajaran ekspositori.

Pada uji hipotesis kedua ini, hipotesis yang akan diuji adalah $H_{0}: \mu B_{1}=\mu B_{2}$ (Regulasi diri siswa tidak berbeda secara signifikan antara antara kelas yang diajarkan dengan menggunakan problem based learning dan kelas yang diajarkan dengan menggunakan pembelajaran ekspositori) melawan $H_{a}: \mu B_{1} \neq \mu B_{2}$ (Regulasi diri siswa berbeda secara signifikan antara antara kelas yang diajarkan dengan menggunakan problem based learning dan kelas yang diajarkan dengan menggunakan pembelajaran ekspositori). Untuk menguji ada atau tidaknya perbedaan regulasi diri siswa kelas V SD Santo Vincentius pada mata pelajaran IPA, peneliti menggunakan independent sample t-test dengan bantuan program SPSS 16.0 for windows. Apabila nilai signifikansi yang diperoleh > 0,05, maka $H_{o}$ diterima. Sebaliknya, apabila nilai signifikansi yang diperoleh $<0,05$, maka $H_{a}$ diterima. Hasil analisis data uji $t$ terhadap skor posttest regulasi diri tersaji pada tabel berikut ini.

Tabel 9. Uji $t$ Terhadap Skor Posttest Regulasi Diri

\begin{tabular}{rccc}
\hline Variabel & t & df & Sig. (2-tailed \\
\hline Regulasi diri & 2,882 & 68 & 0,005 \\
\hline
\end{tabular}

Berdasarkan tabel 9 yang disajikan, dapat diketahui bahwa nilai signifikansi yang diperoleh adalah sebesar 0,005. Nilai signifikansi yang diperoleh lebih kecil dibandingkan dengan nilai alpha yang telah ditetapkan yaitu 0,05 , maka $H_{o}$ ditolak. Oleh karena itu, dapat disimpulkan bahwa terdapat perbedaan regulasi diri siswa yang signifikan antara kelas yang diajarkan dengan menggunakan problem based learning dan kelas yang diajarkan dengan menggunakan pembelajaran ekspositori.

Untuk mengetahui lebih lanjut mengenai peningkatan skor, maka peneliti menghitung rerata gain ternormalisasi (average normalized gain) dengan menggunakan rumus sebagaimana yang diungkapkan oleh Hake (1998, p.65). Adapun rumus untuk menghitung rerata gain ternormalisasi adalah sebagai berikut.

$$
(G)=\%(G) / \%(G)_{\max }=\left(\%\left(S_{j}\right)-\%\left(S_{i}\right)\right) /\left(100-\%\left(S_{i}\right)\right)
$$

Atau diperjelas sebagai berikut.

$$
\text { (g) }=\frac{\text { Rerata shor posttest-Rerata shor pretest }}{\text { Shor Total-Rerata shor pretest }}
$$

Berdasarkan perhitungan gain skor tersebut, maka peneliti merangkum hasil perolehan gain skor kedua kelompok pada tabel berikut ini.

Tabel 10. Rangkuman Perolehan Gain Skor

\begin{tabular}{lcc}
\hline \multicolumn{1}{c}{ Variabel } & $\begin{array}{c}\text { Kelas } \\
\text { Kontrol }\end{array}$ & $\begin{array}{c}\text { Kelas } \\
\text { Eksperimen }\end{array}$ \\
\hline Berpikir kritis & 0,17 & 0,25 \\
Regulasi diri & 0,11 & 0,38 \\
\hline
\end{tabular}

Berdasarkan tabel 10, dapat diketahui perolehan gain untuk variabel keterampilan berpikir kritis dan regulasi diri pada kelas kontrol secara berturut-turut adalah 0,17 dan 0,11. Perolehan gain pada kelas eksperimen untuk ketiga variabel secara berturut-turut adalah 0,25 dan 0,38 . Berdasarkan data perbandingan peningkatan rerata gain skor kedua kelompok, maka dapat disimpulkan bahwa kelompok eksperimen mengalami peningkatan rerata skor yang lebih tinggi dibandingkan kelompok kontrol.

Untuk mengklasifikasikan masingmasing perolehan gain skor, peneliti membandingkannya dengan kriteria perolehan gain skor yang tersaji pada tabel di bawah ini.

Tabel 11. Kategori Perolehan Gain Skor

\begin{tabular}{cc}
\hline Kriteria & Keterangan \\
\hline$(\langle g\rangle) \geq 0,7$ & Tinggi \\
$0,7\rangle(\langle g\rangle) \geq 0,3$ & Sedang \\
$(\langle g\rangle)<0,3$ & Rendah \\
\hline
\end{tabular}


Berdasarkan kategori perolehan gain skor pada tabel 11, maka dapat disimpulkan bahwa peningkatan rerata gain skor untuk variabel keterampilan berpikir kritis dan regulasi diri siswa masih tergolong pada kategori rendah. Pada kelas eksperimen peningkatan rerata gain skor pada variabel regulasi diri tergolong pada kategori sedang sedangkan untuk variabel keterampilan berpikir kritis masih tergolong pada kategori rendah.

Berdasarkan perolehan gain skor, diketahui bahwa keterampilan berpikir kritis siswa yang diajar dengan menggunakan model problem based learning masih tergolong rendah walaupun perolehan gain skornya masih lebih tinggi bila dibandingkan siswa yang diajar dengan menggunakan pembelajaran ekspositori. Hal ini disebabkan oleh model pembelajaran ini baru pertama kali diterapkan di kelas sehingga siswa belum terbiasa. Untuk mengembangkan keterampilan berpikir kritis siswa, dibutuhkan latihan dan pembiasaan melalui serangkaian kegiatan pembelajaran yang melibatkan siswa dalam pencarian informasi dan kegiatan dialog, baik dengan siswa lainnya maupun dengan guru.

Untuk menguji apakah penerapan model pembelajaran problem based learning berpengaruh secara signifikan terhadap keterampilan berpikir kritis dan regulasi diri siswa kelas V SD Santo Vincentius pada mata pelajaran IPA, digunakan uji multivariat yaitu Hotelling's Trace. Hasil uji multivariat yang tersaji pada tabel 12

Berdasarkan data yang tersaji pada tabel 12, diketahui nilai $\mathrm{F}$ test untuk Hotelling's Trace adalah sebesar 4,095 dengan nilai signifikansi sebesar 0,021. Nilai signifikansi yang diperoleh lebih kecil dari nilai alpha yang ditetapkan yaitu 0,05. Dengan demikian, dapat disimpulkan bahwa penerapan model pembelajaran problem based learning berpengaruh secara positif dan signifikan terhadap keterampilan berpikir kritis dan regulasi diri siswa kelas V SD Santo Vincentius pada mata pelajaran IPA.

Tabel 12. Uji Multivariat Hotelling's Trace

\begin{tabular}{ccccc}
\hline Value & F & Hypothesis df & Error df & Sig \\
\hline 0,122 & 4,095 & 2 & 67 & 0,021 \\
\hline
\end{tabular}

Kesimpulan yang diperoleh berdasarkan analisis data tersebut memperkuat pendapat Christensen \& Martin (dalam Killen, 2009, p.248), yaitu melalui kegiatan pemecahan ma- salah, siswa dapat mengembangkan keterampilan berpikir kritis. Masalah yang disajikan oleh guru yang berupa laporan terjadinya peristiwa alam baik gempa bumi dan banjir yang memberi dampak kerugian bagi manusia termasuk siswa di dalamnya, menimbulkan keingintahuan siswa untuk menemukan bagaimana caranya agar masalah tersebut dapat dipecahkan.

Dalam kolaborasi siswa dengan anggota kelompoknya, siswa mendapat kesempatan untuk mengemukakan pendapat berdasarkan pengetahuan yang dimilikinya terkait masalah yang sedang dibahas oleh kelompok. Dialog antar siswa muncul karena adanya perbedaan pengetahuan yang dimiliki siswa. Masingmasing siswa mengemukakan apa yang diketahuinya berdasarkan apa yang telah mereka baca, dengar dan mereka alami. Dengan adanya perbedaan tersebut, siswa termotivasi mencari informasi dari berbagai sumber, baik dari buku, internet atau bertanya dengan orangtua untuk menguji kebenaran atas pemikirannya.

Melalui proses mencari informasi ini, siswa banyak memperoleh informasi baru sehingga terjadi proses yang diistilah Piaget sebagai proses asimilasi dan akomodasi. Asimilasi terjadi ketika siswa menambahkan informasi-informasi baru ke dalam pengetahuannya sedangkan akomodasi terjadi ketika terjadi perbedaan informasi yang telah dimilikinya dengan apa yang baru saja diperoleh. Oleh karena itu, terjadi proses penyesuaian terhadap informasi baru. Dengan demikian, dengan adanya kegiatan tersebut maka menimbulkan proses equilibrium dalam diri siswa. Dalam proses tersebut, keterampilan berpikir kritis siswa mengalami perkembangan.

Keterampilan berpikir kritis siswa tidak berkembang begitu saja tanpa adanya dukungan dari guru. Hal ini dikarenakan proses pemecahan masalah bukanlah merupakan proses yang mudah dilakukan oleh siswa. Melalui umpan balik yang diperoleh dari siswa, peneliti menemukan bahwa siswa menganggap bahwa kegiatan memecahkan masalah merupakan hal yang sulit untuk dilakukan. Dalam hal ini, masalah yang harus dipecahkan dianggap sebagai tugas yang sulit untuk diselesaikan oleh siswa, yang diistilahkan Vygotsky sebagai sebuah Zone Proximal Development (ZPD). Namun, siswa menambahkan bahwa dengan bertanya dengan guru, mereka mampu untuk memecahkan masalah tersebut. Artinya, dengan adanya 
scaffolding dari guru, sangat membantu siswa dalam memecahkan masalah yang diberikan.

Sebagaimana yang diungkapkan oleh Christensen \& Martin (dalam Killen, 2009, p.249), kegiatan pemecahan masalah tidak hanya dapat mengembangkan keterampilan berpikir kritis, namun juga dapat memperdalam pemahaman siswa terhadap konsep yang dipelajari. Ketika siswa dilibatkan dalam memecahkan masalah, siswa merasa memiliki peranan dalam usaha untuk menemukan solusi atas masalah yang ada. Melalui pemahaman tersebut, tumbuh kesadaran siswa untuk melakukan tindakan secara nyata dalam memecahkan masalah yang diberikan guru. Kesadaran siswa muncul sejalan dengan bertambahnya pemahaman siswa mengapa suatu tindakan harus dilakukan dan bagaimana dampaknya dari tindakan tersebut.

Dalam kaitannya dengan pembelajaran IPA mengenai gempa bumi dan banjir, siswa menemukan bahwa dampak dari adanya peristiwa gempa bumi dan banjir menimbulkan kerugian bagi masyarakat. Kerugian yang dialami dapat diminimalisir atau bahkan bisa dicegah bila masyarakat melakukan tindakan-tindakan tertentu yang tepat. Ketika siswa dapat menemukan tindakan apa yang tepat untuk dilakukan sebagai sebuah solusi, maka secara tidak langsung, perilaku siswa pun mengalami perubahan. Dengan timbulnya kesadaran untuk memecahkan masalah yang terjadi karena merasa menjadi bagian dari masyarakat, maka siswa belajar untuk mengontrol perilakunya agar sesuai dengan apa yang telah dipelajarinya. Melalui proses inilah, regulasi diri siswa mengalami perkembangan. Dengan demikian, hal ini sesuai dengan pendapat Vygotsky (dalam Diaz, Neal, \& Amaya-Williams, 1990, p.140) yang mengungkapkan bahwa regulasi diri dapat berkembang dengan melibatkan aktivitas-aktivitas siswa dalam memecahkan masalah.

\section{Simpulan dan Saran}

Simpulan

Berdasarkan hasil analisis data dan pembahasan yang telah dilakukan, maka peneliti menyimpulkan sebagai berikut: (1) Terdapat perbedaan keterampilan berpikir kritis siswa kelas V SD Santo Vincentius Jakarta yang signifikan antara kelas yang diajar dengan menggunakan problem based learning dan kelas yang diajar dengan menggunakan pembelajaran ekspositori pada mata pelajaran IPA; (2)
Terdapat perbedaan regulasi diri siswa kelas $\mathrm{V}$ SD Santo Vincentius Jakarta yang signifikan antara kelas yang diajar dengan menggunakan problem based learning dan kelas yang diajar dengan menggunakan pembelajaran ekspositori pada mata pelajaran IPA; dan (3) Penerapan problem based learning berpengaruh secara positif dan signifikan terhadap keterampilan berpikir kritis dan regulasi diri siswa kelas $\mathrm{V}$ SD Santo Vincentius pada mata pelajaran IPA.

Saran

Berdasarkan simpulan, implikasi, dan keterbatasan dari penelitian ini, maka peneliti memberikan saran sebagai berikut: (1) Kepada guru sekolah dasar agar dapat menggunakan model problem based learning yang dapat mengembangkan keterampilan berpikir kritis dan regulasi diri melalui penyajian masalah yang menarik bagi siswa; (2) Kepada sekolah, khususnya kepala sekolah agar dapat memberi kesempatan untuk pengembangan kompetensi guru dalam menerapkan model problem based learning, mulai dari tahap perencanaan pembelajaran hingga pada proses penilaian siswa; (3) Kepada peneliti yang hendak melakukan penelitian yang serupa agar mengembangkan masalah-masalah yang lebih menarik untuk dipecahkan oleh siswa dan mengoptimalkan setiap fase dalam problem based learning; dan (4) Dalam penelitian lanjutan, peneliti perlu mengembangkan pedoman observasi untuk mengukur sikap berpikir kritis dan kemampuan regulasi diri siswa.

\section{Daftar Pustaka}

Anderson, L.W \& Krathwohl, D.R. (2010). Kerangka landasan untuk pembelajaran, pengajaran, dan asesmen: revisi taksonomi bloom. (Terjemahan Agung Prihantoro). New York: Addison Wesley Longman, Inc. (Buku asli diterbitkan pada tahun 2001).

Arends, R.I \& Kilcher, A. (2010). Teaching for learning: becoming an accomplished teacher. New York: Routledge.

Azwar, Saifuddin. (2012). Metode penelitian. Yogyakarta: Pustaka Pelajar.

Chiapetta, E.L \& Kolballa, T.R. (2010). Science instruction in the middle and secondary schools $\left(7^{\text {th }}\right.$ ed.). Boston: Pearson Education, Inc. 
Diaz, R.M, Neal, C. J, \& Amaya-Williams, M. (1990). The social origins of selfregulation. Dalam L.C. Moll (Ed). Vygotsky and education: instructional implications of sociohistorical psychology (pp 127-154). Victoria: Cambridge University Press.

Facione, P. A. (2011). Critical thinking: what its is and why it counts. Diambil pada tanggal 16 Juli 2012, dari http://www.insightassessment.com

Hake, R.R. (1998). Interactive-engagement versus traditional methods: a six thousand-student survey of mechanics test data for introductory physics courses. Diambil pada tanggal 25 Juli 2013, dari http://web.mit.edu/rsi/www/2005/misc/ minipaper/papers/Hake.pdf

Howe, A.C \& Jones, L. (1993). Engaging children in science. New York: Macmillan Publishing Company.

Killen, R. (2009). Effective teaching strategies: lessons from research and practice $\left(5^{\text {th }}\right.$ ed.). Victoria: Cencage Learning.

King, F.J, Goodson, L \& Rohani, F. (1998). Higher order thinking skills: definition, teaching \& assessment. Diambil pada tanggal 16 Juli 2012, dari http://www.cala.fsu.edu/files/higher_or der_thinking_skills.pdf

Moore, B \& Stanley, T. (2010). Critical thinking and formative assesment: increasing the rigor in your classroom. Larchmont: Eye On Education, Inc.

Partnership For $21^{\text {st }}$ Century Skills. (2009). P21 framework definitions. Diambil pada tanggal 16 Februari 2011, dari http://www.21 centuryskills.org

Rusmono. (2012). Strategi pembelajaran dengan problem based learning itu perlu. Bogor: Ghalia Indonesia.

Samatowa, Usman. (2011). Pembelajaran ipa di sekolah dasar. Jakarta: PT. Indeks Santrock, J.W.(2010). Psikologi pendidikan $\left(2^{\text {th }}\right.$ ed.). (terjemahan Tri Wibowo B.S). Jakarta: Kencana Prenada Media Group. (Buku asli diterbitkan pada tahun 2004).

Schunk, D.H. (2012). Teori-teori pembelajaran: perspektif pendidikan (6 ${ }^{\text {th }}$ ed.). (terjemahan Eva Hamdiah \& Rahmat Fajar). Yogayakarta: Pustaka 